
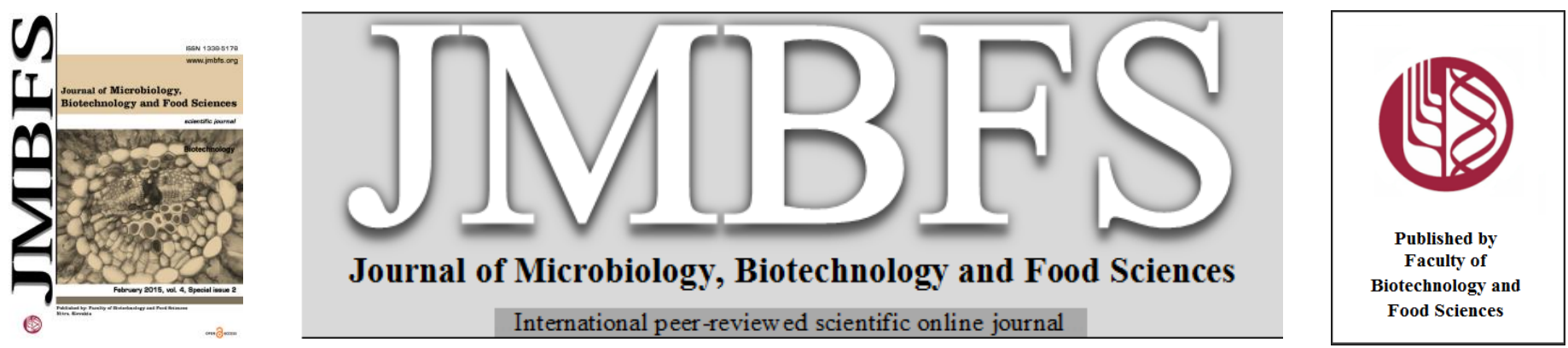

\title{
SEQUENCE ANALYSIS OF SUNDEW CHITINASE GENE
}

\section{Dominika Ďurechová*, Ildikó Matušiková, Jana Moravčiková, Martin Jopčik, Jana Libantová}

Address(es):Ing. Dominika Ďurechová

Institute of Plant Genetics and Biotechnology, Slovak Academy of Sciences, Akademická 2, P. O. Box 39A, 950 07 Nitra, Slovakia, phone number: +421376943350

*Corresponding author: dominika.durechova@savba.sk

doi: 10.15414/jmbfs.2015.4.special2.4-6

\section{ARTICLE INFO}

Received 10. 12. 2014

Revised 17. 12. 2014

Accepted 4. 1. 2015

Published 2. 2. 2015

Regular article

open $\mathcal{O}$ access

\section{INTRODUCTION}

Global food security is the major challenge for biological sciences. As the plants cannot avoid environmental stress they have developed defense mechanisms to alleviate their impact. The inducible defense responses include cell wall reinforcement, lignifications, induction of oxidative burst, hypersensitive cell death, the accumulation of antimicrobial secondary metabolites such as phytoalexins and expression of pathogenesis-related (PR) proteins (Veluthakkal and Dasgupta, 2012). Chitinases (EC3.1.2.14) are particularly interesting plant enzymes because their substrate is not present in plant tissue per se. Their induction has been reported upon fungal infection. Moreover, the experiments performed underin vitro condition, confirmed the capability of some plant chitinases to inhibit growth of several fungal pathogens (Schlumbaumet al. 1986; Theis and Stahl, 2004; Moravckovaet al. 2004, 2007; Van Loon et al. 2006). Based on the primary structures and specific domains plant chitinase have been grouped into seven classes (Collingeet al. 1993; Neuhaus 1999). ClassI, II, IV, VI and VII have glycosyl hydrolase 19 catalytic domain. In addition to class I also class IV and VI harbor chitin-binding domain. Class III and V of enzymes are included in the family 18 of glycosyl hydrolases. They share the consensus sequence DXDXE, but otherwise show very low homology to each other (Melchers et al., 1994; Veluthakkal and Dasgupta, 2012). The presence or absence of a C-terminal extension (CTE) divides chitinases into two subclasses: subclass a (CTE present) and subclass b (CTE absent). Its presence has been shown to be responsible for transport of the protein to the vacuole (Neuhauset al., 1991; Renner and Specht,2012).

In addition to the role of chitinases in defense responses to pathogens class I chitinases have been shown to be important players in plant carnivory in the Caryophyllales. The presence of class I chitinases and their activity was demonstrated within the specialized carnivorous traps of sundew (Drosera) and tropical pitcher plants (Nepenthes) (Matusikovaet al., 2005; Eilenberget al., 2006). Recently we have isolated genomic sequence of $D$. rotundifoliachitinasewhile the TBLASTX confirmed its greatest consistency with the chitinases of Droseraspatulata(AY643483.1), Allium sativum (M94105.1) and Nepenthes khasiana(AY618883.1) with E values $\mathrm{e}^{-158}, \mathrm{e}^{-133}$ and $\mathrm{e}^{-131}$, respectively(吕urechováet al. 2013). Here we bring the in silico analysis of this gene and experimental proof of splicing introns and transcriptional start site.

\section{MATERIAL AND METHODS}

\section{Plant Material}

Plants of Droserarotundifolia L. were cultivated in vitro on basal MS medium (DUCHEFA) supplemented with $2 \%(\mathrm{w} / \mathrm{v})$ sucrose and $0.8 \%(\mathrm{w} / \mathrm{v})$ agar
(Bobáket al., 1995). The plantlets were cultivated at $20 \pm 2{ }^{\circ} \mathrm{C}$ with a day length of $16 \mathrm{~h}$ under $50 \mu \mathrm{Em}^{-2} \mathrm{~s}^{-1}$ light intensity.

\section{In silico analysis}

The structure of $g D r C h i t g e n e$ was analyzed using NetGene2 (http://www.cbs.dtu.dk/services/NetGene2/(Hebsgaardet al., 1996). Motif analysis was conducted using the InterProScansoftware(www.ebi.ac.uk/InterProScan). Predictions of transcription initiation sites were performed using the Neural Network Promoter Prediction (http://www.fruitfly.org/seqtools/promoter) (Reese et al.,1997)

\section{Isolation of total RNA and cDNA synthesis}

Total RNA was isolated from in vitro sundew plants using the protocol described by Békésiováet al.(1999) and treated with RNase-free DNaseI (Thermo Fischer Scientific, USA). First strand cDNA was synthesized using Maxima H Minus First Strand cDNA Synthesis Kit (Thermo Fischer Scientific, USA) and oligo $(\mathrm{dT})_{20}$ primer. Primers ChitStartFOR 5'-AACCATGGGCATTACTATCATGCT3' and ChitSTOREV 5'-TGTTCTAGAAAAAAGGACGCTGATTAT-3'were used to amplify cDNA sequence. PCR program involved one cycle at $94^{\circ} \mathrm{C}$ for 2 min, followed by 40 cycles at $94^{\circ} \mathrm{C}$ for $30 \mathrm{~s}, 58^{\circ} \mathrm{C}$ for $30 \mathrm{~s}, 72^{\circ} \mathrm{C}$ for $40 \mathrm{~s}$ and one cycle at $72^{\circ} \mathrm{C}$ for $10 \mathrm{~min}$. Next the PCR fragment was cloned into pGemT-easy (Promega, USA) was commercially sequenced.

\section{Mapping of the transcription start site}

The 5'end of chitinase transcript was mapped according to the protocol described by Pinto and Lindblad(2010). Total RNA $8.5 \mu 1(1 \mu \mathrm{g})$ was supplemented with $1 \mu \mathrm{l}$ of $10 \mathrm{mMdNTP}$ and $1 \mathrm{mM}$ ChitREV255 $5^{\prime}$ GCTGACATCACCACCTCCACTAGGAGAA-3' primer denaturated at $65{ }^{\circ} \mathrm{C}$ for $5 \mathrm{~min}$, and quickly cooled on ice. Then the mastermix containing $1 \mu \mathrm{l}$ of 25 $\mathrm{mM} \mathrm{MgCl} 2,20 \mathrm{U}$ RNase inhibitor, $3 \mu \mathrm{l}$ of $5 \mathrm{x}$ buffer and $100 \mathrm{U}$ Maxima H Minus reverse transcriptase (Thermo Scientific, USA) was added to the denaturated RNA and cDNA extension proceeded for $60 \mathrm{~min}$ at $50{ }^{\circ} \mathrm{C}$. Next to the mixture was added prewarmed template-switching mastermix containing $1 \mu 1$ of $25 \mathrm{mM}$ $\mathrm{MgCl}_{2}, 100 \mathrm{mM} \mathrm{MnCl}, 100 \mathrm{U}$ reverse transcriptase, $1 \mu \mathrm{l}$ of $5 \mathrm{x}$ buffer and $2 \mu 1$ of 10 of $\mathrm{mM}$ TSOprimer GTCGCACGGTCCATCGCAGCAGTCACAGGGGG-3'), temperature was lowered to $42{ }^{\circ} \mathrm{C}$ and reaction was incubated for additional $120 \mathrm{~min}$. The reaction was inactivated at $85^{\circ} \mathrm{C}$ for $5 \mathrm{~min}$. The $5^{\prime}$ end products were synthesized in two step PCR, using U-sense primer (5'-GTCGCACGGTCCATCGCAGCAGTC-3') and the gene specific primer ChitREV200 5'GCTGGTGGTGGAGAGCTGCCACCACACT3'. In subsequent PCR reaction U-sense primer and ChitREV146 5'- 
GCTGGTGGTGGAGAGCTGCCACCACACT- 3 'were used. The conditions for the first and second PCR were one cycle at $98^{\circ} \mathrm{C}$ for $3 \mathrm{~min}$, followed by 45 cycles at $98^{\circ} \mathrm{C}$ for $15 \mathrm{~s}$ and $72^{\circ} \mathrm{C}$ for $60 \mathrm{~s}$ and one cycle at $72^{\circ} \mathrm{C}$ for $10 \mathrm{~min}$. The $5^{\prime}$ end products were cloned into pGemT-easy (Promega, USA) and sequenced to identify the transcription start site.

\section{RESULTS AND DISCUSSION}

\section{Analysis of genomic Drchit sequence}

The1666 bp DNA fragment of chitinasewas amplified from the ATG start codon to the termination codon. The NetGene 2 online program detected the presence of three exons and two intronswith the size $114 \mathrm{bp}$ and $572 \mathrm{bp}$, respectively (figure1).

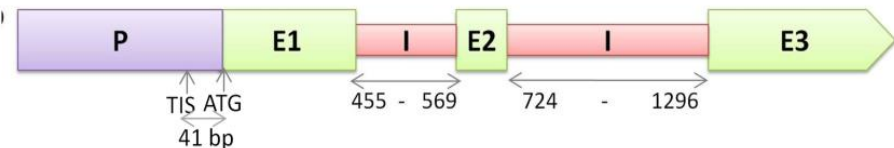

Figure 1 Structural characterization of the Drchit gene. The introns were in silico and experimentally proven at position $455-569 \mathrm{bp}$ and $724-1296 \mathrm{bp}$ from the ATG start codon.

To confirm splicing of the introns, the PCR on cDNA template was performed with ChitStartFor and ChitStopRev primers surrounding the Drchitgene. Following the amplification, the fragment of the length $\sim 950 \mathrm{bp}$ was detected on agarose gel (figure 2).

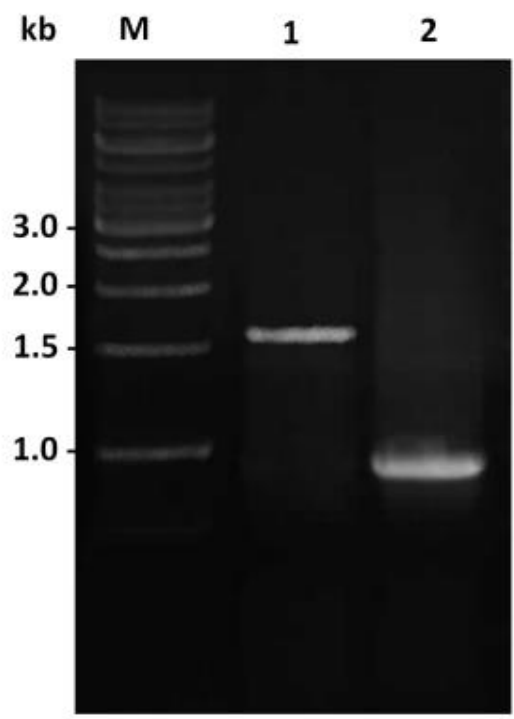

Figure 2 PCR splicing of introns in DrChit gene. PCR with ChitStartFOR and ChitStopREV primers resulted in amplification of $1600 \mathrm{bp}$ fragment on the genomic DNA template (lane 1) and $2950 \mathrm{bp}$ fragment on the cDNA template (lane 2) (Marker - 1 kb DNA ladder SM0312 ThermoScientific).

Analysis of PCR ampliconsequence data confirmed the accordance of intron splicing with results of in silico, performed by NetGene 2 program.Both introns were AT rich $(60.7 \%$ and $65.2 \%$, respectively) and posses consensus splice junction of $5^{\prime}-\mathrm{GGT}^{\mid}$and $3^{\prime}-\mathrm{AG} \mathrm{G}$ for the first intron and $5^{\prime}-\mathrm{A}^{\mathrm{l}} \mathrm{GT}$ and $3^{\prime}-\mathrm{AGC}$ for the second intron. On the other hand, in silico splicing of introns performed by GeneScan program predicted the first and third exon in accordance with an experimental approach, but the second exon differed in itslength.

When experimentally proven intron pattern of the DrChit was compared with other homologous genes, the similarity with other dicots chitinases was reported.Both introns were surrounded by the DNA sequences thatcorresponded at their 5'and 3'ends to amino acids FATT and GWPTA; QIST and NYNY, respectively. Generally, most of the genes encoding plant chitinases are interrupted by an intervening sequence. For example the Arabidopsis class chitinases have one intron (Samacet al., 1990) tobacco chitinase genes have two introns (Van Buurenet al., 1992), while rice chitinase genes were intronless (Zhu and Lamb, 1991).

The nucleotide sequence around the predicted ATG start codon region, AACCATGG is in agreement with the Kozak consensus initiator ANNATGG (Lutzkeetal,.1987) proposed for the translation start of plant genes.

When the 5 'upstream sequence from ATG was investigated by Neural Network Promoter Prediction program for the presence oftranscription start site (TSS) two possible starts of transcription with the position $41 \mathrm{bp}$ and $66 \mathrm{bp}$ from the ATGwere predicted (Ďrechováet al., 2014).To determine functional TSS and 5 'untranslated region of mRNA in in vivo, the template-switch-based 5'RACE was performed.Following the isolation of total RNA from sundew leaves, cDNA synthesis and two-round PCR,a specific fragment of the length $\sim 200$ bp was isolated from the agarose gel, cloned into the pGemT-easy vector and sequenced (figure 3).The sequencing data obtained were in accordance with the transcription start site predicted in silico at the position $41 \mathrm{bp}$ upstream of the ATG.

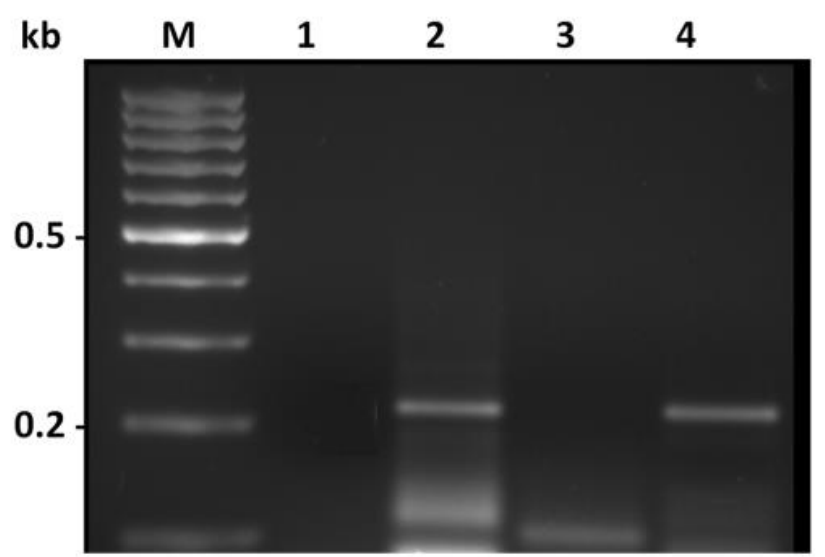

Figure 3 Agarose gel analysis of template-switch-based 5'RACE -PCR products 5'-RACE-PCR were performed on first-strand cDNA prepared from total RNA of leaves Drosrerarotundifoliaplants using the U-sense primer and gene specific primers of ChitREV200 and ChitREV146 and the templates prepared with (lanes 2 and 4) or without reverse transcriptase (lanes 1 and 3) (M- 100 bp DNA ladder SM1143 Thermo Scientific)

The 5'UTR of mRNAs are known to be involved in the translation of genes in response to the environmental stress (Floris et al., 2009). Analysis in silicoshowed that within this short sequence the motifs ACGTATERD1 (Simpsonet al., 2003), MYB2CONSENSUSAT (Abeet al., 2003) and MYBCORE (Uraoet al., 1993) playinga role in dehydrationstresswererevealed. Thepresenceof cis-acting elements in the untranslated region of the PR genes has not been reported so far (Veluthakkal and Dasgupta, 2012).

\section{CONCLUSION}

In conclusion we were able to isolate the chitinase gene from carnivorous plant Droserarotundifolia and make some deducation on the gene architecture through the use of bioinformatic tools. The isolation of total RNA from sundew and amplification of 5 'end ofchitinase confirmed the expression of this gene in sundew plants and revealed the transcription start site $41 \mathrm{bp}$ upstream from the ATG. The template-switch-based 5'RACE system used in our experiment for identification of 5 'end of chitinase have been shown as time-in-efficient and inexpensive comparing to the other commercially available kits.

\section{Acknowledgments:}

This study was supported by the Scientific Grant of the Slovak republic VEGA no. 2/0090/14,COST FA1208 and the European Community under project no 26220220180: Building Research Centre „AgroBioTech".

\section{REFERENCES}

ABE, H., URAO, T., ITO, T., SEKI, M., SHINOZAKI, K., YAMAGUCHISHINOZAKI, K. 2003.Arabidopsis AtMYC2 (bHLH) and AtMYB2 (MYB) function as transcriptional activators in abscisic acid signaling. Plant Cell, 15, 6378. http://dx.doi.org/10.1105/tpc.006130

BEKESIOVA, I., NAP, J. P., MLYNAROVA, L. 1999. Isolation of high quality DNA and RNA from leaves of the carnivorous plant Droserarotundifolia.Plant $\begin{array}{llll}\text { Molecular Biology } & \text { Reporter, } & 17, & 269-277 .\end{array}$ http://dx.doi.org/10.1023/a:1007627509824

BOBAK, M., BLEHOVA, A., KRISTIN, J., OVECKA, M., SAMAJ, J. 1995. Direct plant regeneration from leaf explants of Droserarotundifolia cultured in vitro. Plant Cell Tissue and Organ Culture, 43, 43-49. http://dx.doi.org/10.1007/bf00042670

COLlingE, D. B., KRAGH, K. M., MIKKELSEN, J. D., NIELSEN, K. K., RASMUSSEN, U. \& VAD, K. 1993. Plant chitinase.PlantJournal, 3, 31-40. http://dx.doi.org/10.1046/j.1365-313x.1993.t01-1-00999.x

ĎURECHOVÁ, D., MATUŠÍKOVÁ, I.,MORAVČÍKOVÁ, J., JOPČÍK, M.,LIBANTOVÁ, J. $2013 . \quad$ Isolation and characterizationofchitinasegenefromtheuntraditionalplantspecies.JournalofMicro biology, Biotechnology and FoodSciences, 2, specialissue 1, 2208-2216. 
ĎURECHOVÁ, D., MATUŠÍKOVÁ, I, MORAVČÍKOVÁ, J., JOPČÍK, M. LIBANTOVÁ, J.2014.In silico analysis of chitinase promoter isolated from Droserarotundifolia L. Journal of Microbiology, Biotechnology and Food Sciences, 3, special iss.2, 71-73.

EILENBERG, H., PNINI-COHEN, S., SCHUSTER, S., MOVTCHAN, A., ZILBERSTEIN, A. 2006. Isolation and characterization of chitinase genes from pitchers of the carnivorous plant Nepenthes khasiana.Journal of Experimental Botany, 57, 2775-2784. http://dx.doi.org/10.1093/jxb/er1048

FLORIS, M., MAHGOUB, H., LANET, E., ROBAGLIA, C., MENAND, B. 2009.Post-transcriptional regulation of gene expression in plants during abiotic stress.International Journal of Molecular Sciences, 10, 3168-3185. http://dx.doi.org/10.3390/ijms10073168

HEBSGAARD, S. M., KORNING, P. G., TOLSTRUP, N., ENGELBRECHT, J., ROUZE, P.; BRUNAK, S. 1996. Splice site prediction in Arabidopsis thaliana pre-mRNA by combining local and global sequence information. Nucleic Acids Research, 24, 3439-3452. http://dx.doi.org/10.1093/nar/24.17.3439

LUTCKE, H. A., CHOW, K. C., MICKEL, F. S., MOSS, K. A., KERN, H. F., SCHEELE, G. A. 1987. Selection of AUG initiation codons differs in plants and animals. EMBO Journal, 6, 43-48.

MATUSIKOVA, I., SALAJ, J., MORAVCIKOVA, J., MLYNAROVA, L., NAP, J. P., LIBANTOVA, J. 2005. Tentacles of in vitro-grown round-leaf sundew (DroserarotundifoliaL.) show induction of chitinase activity upon mimicking the presence of prey. Planta, 222, 1020-1027.

MELCHERS, L. S., APOTHEKERDEGROOT, M., VANDERKNAAP, J., PONSTEIN, A. S., SELABUURLAGE, M. B., BOL, J. F., CORNELISSEN, B. J. C., VANDENELZEN, P. J. M., LINTHORST, H. J. M. 1994. A new class of tobacco chitinases homologous to bacterial exo-chitinases displays antifungal activity. Plant Journal, 5, 469-480. http://dx.doi.org/10.1046/j.1365313x.1994.05040469.x

MORAVCIKOVA, J., LIBANTOVA, J., HELDAK, J., SALAJ, J., BAUER, M., MATUSIKOVA, I., GALOVA, Z., MLYNAROVA, L. 2007. Stress-induced expression of cucumber chitinase and Nicotianaplumbaginifolia beta-1,3glucanase genes in transgenic potato plants. ActaPhysiologiaePlantarum, 29, 133-141.

MORAVCIKOVA, J., MATUSIKOVA, I., LIBANTOVA, J., BAUER, M. MLYNAROVA, L. 2004. Expression of a cucumber class III chitinase and Nicotianaplumbaginifolia class I glucanase genes in transgenic potato plants. Plant Cell Tissue and Organ Culture, 79, 161-168.

NEUHAUS, J. M., STICHER, L., MEINS, F., BOLLER, T. 1991.A short Cterminal sequence is necessary and sufficient for the targeting of chitinases to the plant vacuole. Proceedings of the National Academy of Sciences of the United States of America, 88, 10362-10366. http://dx.doi.org/10.1073/pnas.88.22.10362 NEUHAUS, J. M. 1999. Plant chitinases (PR3, PR6, PR8, PR11). In: Pathogenesis-related proteins in plants. Ed. By Datta, S.K; Muthukrishnan S. New York :CRC Press, 77-105.

PINTO, F. L., LINDBLAD, P. 2010. A guide for in-house design of templateswitch-based 5' rapid amplification of cDNA ends systems. Analytical Biochemistry, 397, 227-232. http://dx.doi.org/10.1016/j.ab.2009.10.022

REESE, M. G., EECKMAN, F. H., KULP, D., HAUSSLER, D. 1997. Improved splice site detection in Genie. Journal of Computational Biology, 4, 311-323. http://dx.doi.org/10.1089/cmb.1997.4.311

RENNER, T., SPECHT, C. D. 2012.Molecular and functional evolution of class I chitinases for plant carnivory in the Caryophyllales.Molecular Biology and Evolution, 29, 2971-2985. http://dx.doi.org/10.1093/molbev/mss 106

SAMAC, D. A., HIRONAKA, C. M., YALLALY, P. E., SHAH, D. M 1990.Isolation and characterization of the genes encoding basic and acidic chitinase in Arabidopsis thaliana.Plant Physiology, 93, 907-914. http://dx.doi.org/10.1104/pp.93.3.907

SCHLUMBAUM, A., MAUCH, F., VOGELI, U., BOLLER, T. 1986. Plant chitinases are potent inhibitors of fungal growth. Nature, 324, 365-367.

SIMPSON, S. D., NAKASHIMA, K., NARUSAKA, Y., SEKI, M. SHINOZAKI, K., YAMAGUCHI-SHINOZAKI, K. 2003. Two different novel cis-acting elements of erd1, a clpA homologous Arabidopsis gene function in induction by dehydration stress and dark-induced senescence. Plant Journal, 33 , 259-270. http://dx.doi.org/10.1046/j.1365-313x.2003.01624.x

THEIS, T. \& STAHL, U. 2004. Antifungal proteins: targets, mechanisms and prospective applications. Cellular and Molecular Life Sciences, 61, 437-455. http://dx.doi.org/10.1007/s00018-003-3231-4

URAO, T., YAMAGUCHISHINOZAKI, K., URAO, S., SHINOZAKI, K. 1993. An Arabidopsismyb homolog is induced by dehydration stress and its gene product binds to the conserved myb recognition sequence. Plant Cell, 5, 15291539. http://dx.doi.org/10.2307/3869736

VAN LOON, L. C., REP, M., PIETERSE, C. M. J. 2006. Significance of inducible defense-related proteins in infected plants. Annual Review of Phytopathology, 44 ,

$135-162$ http://dx.doi.org/10.1146/annurev phyto.44.070505.143425

VANBUUREN, M., NEUHAUS, J. M., SHINSHI, H., RYALS, J., MEINS, F. 1992.The structure and regulation of homeologoustobacco endochitinase genes of Nicotianasylvestris and $N$. tomentosiformis origin.Molecular \& General Genetics, 232, 460-469
VELUTHAKKAL, R., DASGUPTA, M. G. 2012. Isolation and characterization of pathogen defence-related class I chitinase from the actinorhizal tree

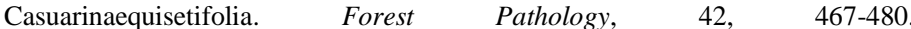
http://dx.doi.org/10.1111/j.1439-0329.2012.00781.X

ZHU, Q., LAMB, C. J. 1991. Isolation and characterization of a rice gene encoding a basic chitinase. Molecular\&GeneralGenetics, 226, 289-296. http://dx.doi.org/10.1007/bf00273615 